\title{
Effects of long term raw pig slurry inputs on nutrient and metal contamination of tropical volcanogenic soils, Uvéa Island (South Pacific)
}

\author{
P. Gunkel-Grillon ${ }^{\mathrm{a}, *}$, E. Roth ${ }^{\mathrm{b}}$, C. Laporte-Magoni ${ }^{\mathrm{a}}$, M. Le Mestre $^{\mathrm{a}}$ \\ a PPME, Université de la Nouvelle-Calédonie BPR4, 98851 Nouméa Cedex, New Caledonia \\ b GSMA, UMR CNRS 7331, Université de Reims Champagne Ardenne, UFR Sciences Exactes et Naturelles, Moulin de la House, BP 1039-51687 Reims Cedex 2, France
}

\section{H I G H L I G H T S}

- Pig slurry dispersal induces heavy metals contamination in mixed calcareous soils.

- In impacted mixed calcareous soils phosphorus and heavy metals are exchangeable.

- In impacted pure ferralitic soils phosphorus and most heavy metals are immobilized.

- Family pig breeding and pig slurry dispersal should be restricted on coastal soils.

\section{A R T I C L E I N F O}

\section{Article history:}

Received 30 March 2015

Received in revised form 18 June 2015

Accepted 24 June 2015

Available online 11 July 2015

Editor: F.M. Tack

\section{Keywords:}

Pig slurry

Heavy metals

Leaching risk

Tropical soils

Family pig breeding

Contamination Factor

Nutrients

metal mobility
G R A P H I C A L A B S T R A C T

\section{Family pig breeding}

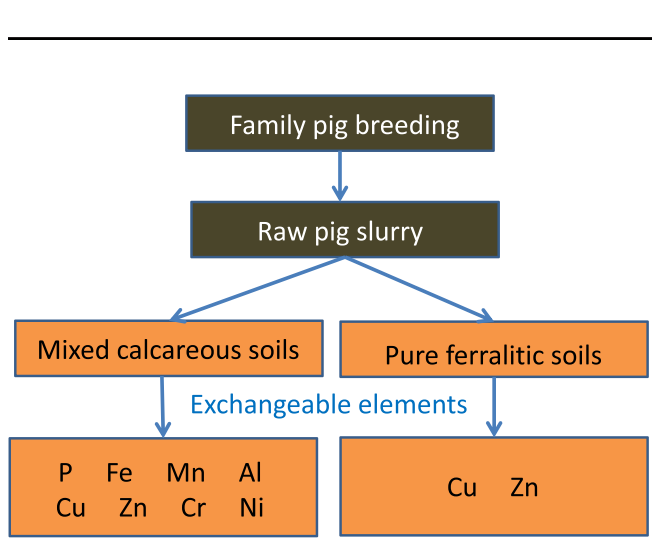

\section{A B S T R A C T}

In small Polynesian islands, family pig breeding is usually conducted without recovery of pig slurry. Raw pig slurry is spread onto the soil without any treatment. So far, most of the studies were carried out in temperate climate and for industrial digested pig slurry applications on agricultural lands. In the present case study, conducted in Uvéa Island, the aim is to determine if long term application of raw pig slurry on tropical soils, naturally rich in heavy metals has a significant influence on elements concentrations and mobility. Two types of tropical soils and two pig breeding systems, pig enclosure on small concrete pens or pig enclosure in large land pens, were investigated. Here we demonstrate that raw pig slurry inputs on soils can lead to an increase of total nitrogen and phosphorus content with high Contamination Factors. The Pollution Load Index values $(1.3 ; 5.3 ; 2.5 ; 2.3)$ were indicative of multi-heavy metals pollution ( $\mathrm{Fe}, \mathrm{Mn}, \mathrm{Al}, \mathrm{Cu}, \mathrm{Zn}, \mathrm{Cr}$ and $\mathrm{Ni}$ ) in mixed calcareous soils of the coastal area and they are exchangeable while they are immobilized or less mobile in inland pure ferralitic soils. For mixed calcareous soils of the coastal area, family pig breeding represents a drainage risk of soluble species (phosphorus, inorganic nitrogen, $\mathrm{Fe}, \mathrm{Mn}, \mathrm{Al}, \mathrm{Cu}, \mathrm{Zn}, \mathrm{Cr}$ and $\mathrm{Ni}$ ). For inland ferralitic soils, family pig breeding is more compatible with a sustainable management of the environment in Uvéa Island and by extension in volcanic tropical islands with respect to the investigated chemical elements.

(C) 2015 Published by Elsevier B.V.

\footnotetext{
* Corresponding author.

E-mail address: peggy.gunkel-grillon@univ-nc.nc (P. Gunkel-Grillon).
}

\section{Introduction}

In the Polynesian culture, pig breeding plays a major role in the political-economic and socio-religious system since social events (wedding, funerals, communion...) are underlined by pig meals cooked 
in traditional earth ovens. Thus inhabitants have a pig breeding near their family houses. As a result, porcine density is significant for these small islands. Uvéa Island, a tropical island in the Territory of Wallis and Futuna Islands, has been chosen as a case study: in 2002, the number of pigs was estimated to be 2 to 15 per inhabitant in Wallis and Futuna (Fediavesky and Angus, 2002). The absence of traffic and industrial activities and the limited urbanization guarantees that Pig Slurry (PS) input was the main anthropogenic factor impacting surface soils' quality. Thus, it represented one of the best experimental sites to study PS impacts on tropical soils.

PS is well-known to be a source of organic matter, micronutrients (Fangueiro et al., 2010; Provolo and Martinez-Suller, 2007) but also high levels of $\mathrm{Cu}, \mathrm{Zn}, \mathrm{Fe}, \mathrm{Mn}$, Co and Cd (L'Herroux et al., 1997; Sánchez and González, 2005). In industrialized countries, many studies have shown the negative effects of intensive PS spreading for fertilization in modern agriculture practices leading to an increase of nitrogen, phosphorus and heavy metals such as $\mathrm{Cu}, \mathrm{Zn}, \mathrm{Co}, \mathrm{Mn}$ in soil layers and/or ground water. These elements can remain in the soil or migrate by percolation or water run off inducing soil and water resources pollution (L'Herroux et al., 1997). Pig breeding in small Polynesian Islands is managed by households without PS management involving those piggeries effluents to be spread directly onto the soil. Family piggeries are mostly located on the coastal area which is particularly sensitive to inputs from the surface. On the coastal area, the groundwater is, indeed, showing on the soil surface. Even though family pig breeding is smaller in size as compared to industrial breeding, the absence of PS recovery induces a major risk of soil and water pollution. Moreover, volcanogenic tropical soils have naturally high metal contents (Doelsch et al., 2010). Thus PS inputs may affect soil physico-chemical parameters ( $\mathrm{pH}$, Eh, organic matter content, salinity ...) and consequently may affect metals speciation and mobility (Acosta et al., 2011; Gunkel et al., 2002). The risk of drainage of soluble species, inorganic nitrogen and soluble phosphorus, essential or detrimental metals provided by PS has to be evaluated. The influence of raw PS on the mobility of endogenous metals, naturally present at high concentrations in tropical soils, has to be evaluated as well.

Recent scientific studies confirmed the impact of PS on tropical soils physico-chemical properties' (Doelsch et al., 2010; Legros et al., 2013) in the case of well managed pig wastes and PS applications. It is well known that the chemical composition of PS has a great variability depending on storage conditions, on farming practices, on diets and also on the type of operation (Hansen et al., 2007; Sánchez and González, 2005). To our knowledge, no data are available for family farming conducted without PS management practices on tropical soils.

The objectives of the present study were then:

(1) to determine the chemical composition of the raw PS produced by family farms;

(2) to evaluate nitrogen and phosphorus content in soils impacted by long term raw PS inputs;

(3) to compare metals ( $\mathrm{Ca}, \mathrm{Mg} \mathrm{Na}, \mathrm{K}, \mathrm{Fe}, \mathrm{Mn}, \mathrm{Al}, \mathrm{Cu}, \mathrm{Zn}, \mathrm{Cr}, \mathrm{Ni}, \mathrm{Cd}$ and $\mathrm{Pb}$ ) contents and mobility; and

(4) to compare the two family pig breeding systems: pig enclosure in small concrete pens and in large land pens.

\section{Materials and methods}

\subsection{Description of studied sites}

Uvéa, located in the Pacific Ocean, is in the Territory of Wallis and Futuna Islands (Fig. 1). The mean annual temperature is $28.6 \pm 0.6^{\circ} \mathrm{C}$ and the mean annual rainfall is $2.87 \pm 1.68 \mathrm{~m} /$ year over the period 1973 to 1995 (Alory and Delcroix, 1999). The climate is tropical, hot and humid all over the year. Except for July (lowest precipitations) and April (highest precipitations), there is quite constant high temperature and high monthly precipitations all over the year. The field campaign was conducted from 16th to 23th May 2011 and we can expect our data to be overall representative for an entire year. The island has an area of $96 \mathrm{~km}^{2}$ and the population density is about $111.8 \mathrm{ih} / \mathrm{km}^{2}$. The coastal strip and the first level plateau cumulate nearly all the population. The unique water resource is a groundwater reservoir which is refilled by annual precipitations and leaching across permeable basalts (Price et al., 1991; Stearns, 1945). It is thus particularity sensitive to surface inputs, especially at the periphery of the island because of the small soil thickness and of the presence of permeable calcareous sand. Contaminants can then easily reach the water resource by percolation at the coastal areas.

Three volcanic units are described with few geochemical variations (Price et al., 1991). Tropical volcanite alteration, impulsed 0,5 Ma ago, results in classical pure ferralitic soils (Tercinier, 1971). However, along the coast, volcanogenic alterites are mixed with calcareous clasts. Then three sites were selected (Fig. 1) to be representative of the pedological diversity that prevails in Uvéa. At Vaïlala, two impacted soils were sampled $A_{1}\left(13^{\circ} 13.221^{\prime} \mathrm{S}, 176^{\circ} 176.198 \mathrm{~W}\right)$ and $\mathrm{A}_{2}\left(13^{\circ} 13.265^{\prime} \mathrm{S}\right.$, $176^{\circ} 12.003 \mathrm{~W}$ ) as well as their respective controls. According to the soils texture diagram (USA Taxonomy 1976) soils $A_{1}$ (sand $68.4 \%$, silt $28.4 \%$ and clay $3.2 \%$ ) and $A_{2}$ (sand $60.9 \%$, silt $35.2 \%$ and clay $3.9 \%$ ) are classified as sandy loam soil. At Mont-Afala $\left(13^{\circ} 15.941^{\prime} \mathrm{S}\right.$, $\left.176^{\circ} 10.919 \mathrm{~W}\right)$ and at Lanutavake $\left(13^{\circ} 19.517^{\prime} \mathrm{S}, 176^{\circ} 12.759^{\prime} \mathrm{W}\right)$ four impacted soils were sampled, $B_{1}, B_{2}$ and $C_{1}, C_{2}$ respectively and their controls. Soils $B_{1}$ and $B_{2}$ (sand $19 \%$, silt $72.9 \%$ and clay $8.1 \%$ ) are classified as silt loam soil and soils $C_{1}$ and $C_{2}$ (sand $5.1 \%$, silt $85.4 \%$ and clay $9.5 \%$ ) are classified as silt soil.

\subsection{Description of farming practices}

Pig diets are traditionally made up of banana leaves, coconut, cassava root (manioc), and food wastes. Nowadays, diets include commercial pellets in a ratio of 25 to almost $100 \%$ of the diet. Pig's diets having an influence on chemical composition on PS (Hansen et al., 2007), we selected farms with 30 to $70 \%$ of the diets supplied by pellets.

Two kinds of pig production systems are in use (Fig. 2) and in both cases PS is not collected in a pit.

- Pigs are enclosed in small concrete pens with a density of 0.5 to 1.2 $\mathrm{pig} / \mathrm{m}^{2}$. The concrete pens are daily cleaned with a jet of water. Wash waters with urine and feces run off onto the soil and accumulate along the concrete pen on a soil surface of around one meter wide. PS is here a mixture of pigs' excretions and water.

- Pigs are enclosed in large land pens (100 to $600 \mathrm{~m}^{2}$ ) and with a pig density of 0.02 to $0.06 \mathrm{pig} / \mathrm{m}^{2}$. PS is here pigs' excretions (urine and feces) emitted directly on the land floor. After 3 years in use the land pen is displaced and the soil is used as an agricultural land to take advantage of the fertilizing effects of PS accumulation.

\subsection{Sampling}

\subsubsection{PS sampling}

Just after a daily washing, four samples were collected in the slurry band along the concrete pens. Samples were separated as liquid and solid phases by centrifugation and analyzed separately.

\subsubsection{Soil sampling}

Samples were collected at various depths: at the surface $(0-5 \mathrm{~cm})$, at $25 \mathrm{~cm}$ and at $65 \mathrm{~cm}$. Five samples were retrieved at each of the 10 sampling plots (on a surface of about $0.5 \mathrm{~m}^{2}$ ) of the three sites leading to the collection of 150 samples. The five samples representative for one plot were pooled and mixed as a single sample to reduce the number of samples to 30 . Pig breedings were surrounded by the tropical forest and the original forest remained 

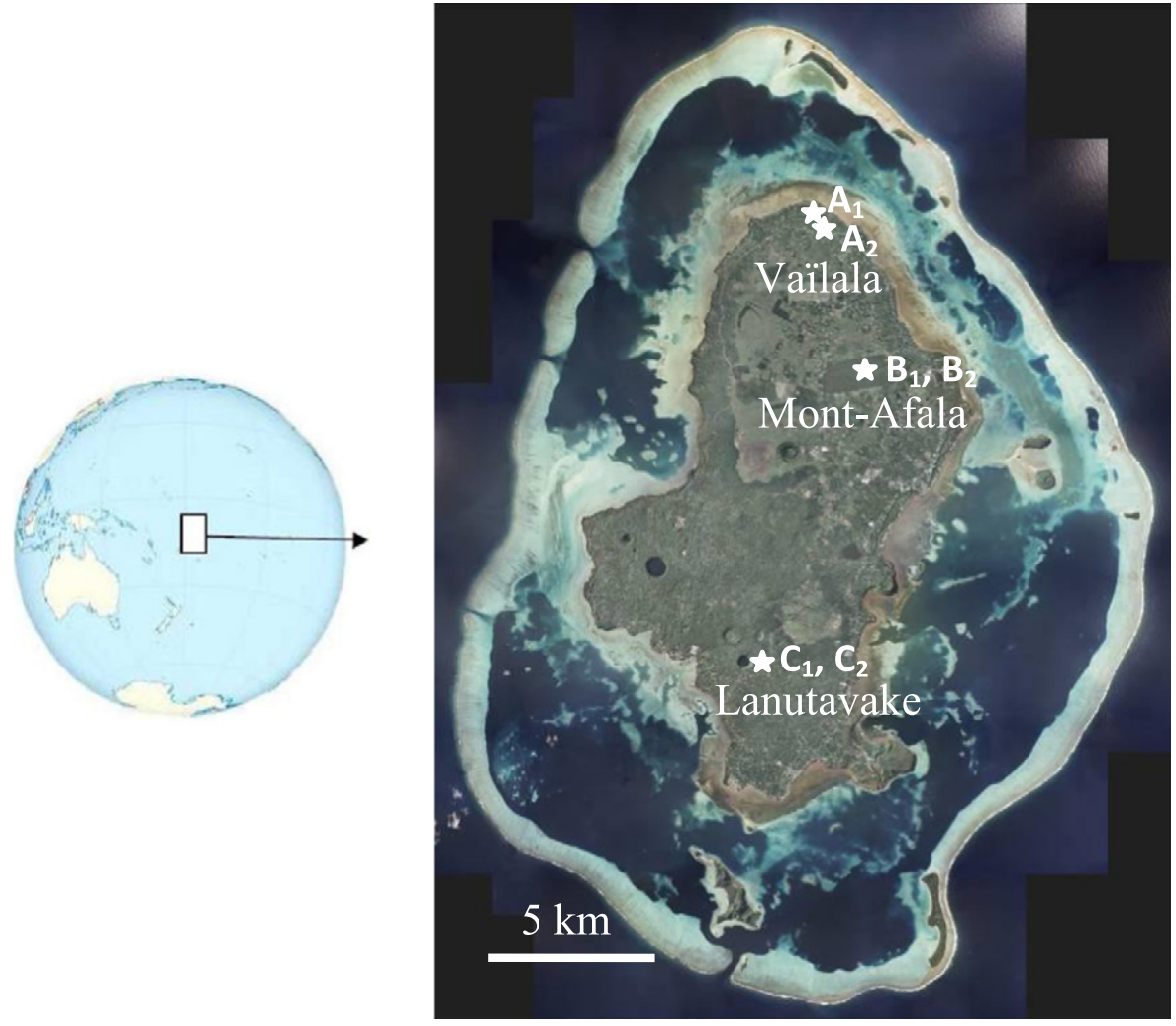

Fig. 1. Location of Uvéa Island and of the three studied sites.

the only area not influenced by PS since deforestation occurred mainly for infrastructures (roads, houses...), crops and breeding. Controls were non-impacted soils collected in the original forest near the breeding area. The subscript $1\left(A_{1}, B_{1}, C_{1}\right)$ was for samples collected near concrete pens, soils have been daily impacted by PS inputs for more than 7 years. Sampling was performed in the middle of the discharge area, after removing the slurry in order to collect soil sample (Fig. 2). The subscript $2\left(A_{2}, B_{2}, C_{2}\right)$ was for samples collected in land pens, soils have been impacted daily by PS inputs for at least one year but no more than three years. Sampling was performed in the dirtiest area which was a preferential area of pig excretion containing lots of pig feces (Fig. 2).

All samples were frozen before aircraft transport and analysis.

\subsection{PS and soil chemical analysis}

The dry matter of samples (soils and of PS solid phase) was determined by drying at $105{ }^{\circ} \mathrm{C}$ for $12-20 \mathrm{~h}$ until a constant weight was reached.

Electrical conductivity (EC) and $\mathrm{pH}$ were measured on PS liquid phase, on water extracts of soils or PS solid phase. $1 / 5(\mathrm{w} / \mathrm{w})$ extracts were prepared by mechanically shaking $20 \mathrm{~g}$ of solid sample in $100 \mathrm{~mL}$ of deionizied water for $1 \mathrm{~h}$, followed by $1 \mathrm{~h}$ of undisturbed settling before measurement. The Total Inorganic Nitrogen $\left(\mathrm{TIN}=\mathrm{N}-\mathrm{NO}_{3}^{-}\right.$ $+\mathrm{N}-\mathrm{NO}_{2}^{-}+\mathrm{N}-\mathrm{NH}_{4}^{+}$) in water extracts was determined by colorimetry with a WTW Measurement System. The Total Kjeldahl Nitrogen (TKN) content was determined by the Kjeldahl method.
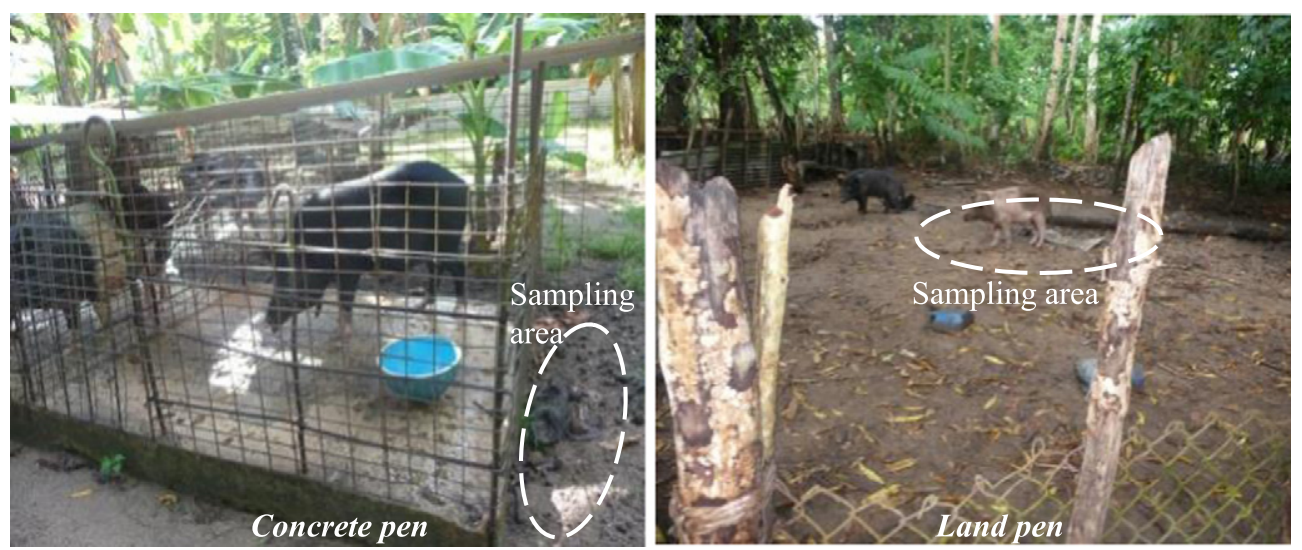

Fig. 2. Family pig farming systems: enclosure of pigs in small concrete pens or in a large land pens. 
PS and soil samples were analyzed for Total Phosphorus (TP) and total metal content ( $\mathrm{Ca}, \mathrm{Mg}, \mathrm{Sr}, \mathrm{Na}, \mathrm{K}, \mathrm{Fe}, \mathrm{Mn}, \mathrm{Al}, \mathrm{Cu}, \mathrm{Zn}, \mathrm{Ni}, \mathrm{Cr}, \mathrm{Pb}$ and Cd) after alkaline digestion $\left(\mathrm{Li}_{2} \mathrm{~B}_{4} \mathrm{O}_{7} / \mathrm{LiBO}_{3}\right.$ at $1100{ }^{\circ} \mathrm{C}$ (NF ISO 14869-2)).

TKN and TP contents in PS liquid phase couldn't be determined because of the small amount of the liquid phase.

A selective extraction procedure using ammonium nitrate solution (1 $\mathrm{mol} / \mathrm{L}$ for a ratio of $1 / 2.5(\mathrm{~m} / \mathrm{V}$ ) according to the standard procedure ISO/DIS19730 (2006)) was performed on soil samples collected at $0-5 \mathrm{~cm}$ depth in order to access the exchangeable fraction of $\mathrm{P}, \mathrm{Ca}, \mathrm{Mg}, \mathrm{Sr}, \mathrm{Na}, \mathrm{K}, \mathrm{Fe}, \mathrm{Mn}, \mathrm{Al}, \mathrm{Cu}, \mathrm{Zn}, \mathrm{Ni}, \mathrm{Cr}, \mathrm{Pb}$ and $\mathrm{Cd}$.

Metals quantification was carried out by ICP-OES (Optima 3300 VD, PerkinElmer). Quality control included triplicate analyses and analytical Standard Deviation (RSD) was below 7\%. Metal concentrations in blanks were below the detection limit.

\subsection{Contamination Factor (CF) and Pollution Load Index (PLI)}

Contamination Factor and Pollution Load Index were both used in this study to examine the contamination of soils. They have been widely used to assess heavy metals contamination in various environments (Gwod et al., 2010; Iqbal and Shah, 2011; Li et al., 2014). Many studies used the average values of shale or crustal abundance as a reference baseline. Since no data on background concentrations for Uvéa Island were available, the alternative was to compare concentrations between contaminated soils and controls.

- CF was calculated for each soil according to Eq. (1) :

$$
\mathrm{CF}=\frac{[\mathrm{X}]_{\text {impacted }}}{[\mathrm{X}]_{\text {control }}}
$$

with $[X]_{\text {impacted }}$ the concentration of the element $\mathrm{X}$ in a soil impacted by PS and $[X]_{\text {control }}$ the concentration of $X$ with the same unit in the soil control at the same depth. CF was calculated for total concentrations (Table 3) and for exchangeable concentrations (Table 5) in order to get the influence of PS on metal mobilization. CF were classified as nil or low when $\mathrm{CF} \leq 1.0$, as moderate when $1.0<\mathrm{CF} \leq 3.0$, as considerable when $3.0<\mathrm{CF} \leq 6.0$ and as very high when $\mathrm{CF}>6$ (Fujita et al., 2014; Håkanson, 1980).

- The PLI was the nth root of the product of the CF determined for the $\mathrm{n}$ studied metals (here $\mathrm{Fe}, \mathrm{Mn}, \mathrm{Al}, \mathrm{Cu}, \mathrm{Zn}, \mathrm{Cr}$ and $\mathrm{Ni}: \mathrm{n}=7$ ) according to Eq. (2):

$$
\mathrm{PLI}=\left(\prod_{\mathrm{i}}^{\mathrm{n}} \mathrm{C} \mathrm{F}_{\mathrm{i}}\right)^{1 / \mathrm{n}}
$$
1980)

\section{Results and discussion}

\subsection{Chemical composition of raw PS (Table 1)}

The $\mathrm{pH}$ of raw PS recorded in Uvea ranged from6.7 to 7.6, according to values found in the literature (6.7 to 9.8) (De la Torre et al., 2000; Moral et al., 2005; Payet et al., 2009; Provolo and Martinez-Suller, 2007; Van der Stelt et al., 2005).

EC of liquid and solid phase ranged from 1.5 to $2.3 \mathrm{dS} . \mathrm{m}^{-1}$. Digested PS collected in tanks have higher EC (1.5 to $75.2 \mathrm{dSm}^{-1}$ ) (De La Torre et al., 2000; Moral et al., 2005; Provolo and Martinez-Suller, 2007; Sánchez and González, 2005) indicating that the soluble ions content was lower than in digested PS.

The solid phase contained high contents of TKN and TP (3.1 to 14.2 g. $\mathrm{kg}^{-1}$ ) in agreement with the literature (Legros et al., 2013; Sánchez and González, 2005). TIN content was low in liquid and solid phases ( 0.4 to $12.0 \mathrm{mg} . \mathrm{L}^{-1}$ and 0.003 to 0.011 g. $\mathrm{kg}^{-1}$ respectively) because around one thousand less concentrated than for industrial digested PS (0.4 to $10.8 \mathrm{~g} / \mathrm{kg}$, Sánchez and González (2005); $2.8 \mathrm{~g} / \mathrm{kg}$, Fangueiro et al. (2010)). These findings are in agreement with EC results.

The liquid phase was a significant source of $\mathrm{K}, \mathrm{Na}, \mathrm{Ca}, \mathrm{Mg}, \mathrm{Fe}, \mathrm{Al}, \mathrm{Mn}$ and $\mathrm{Sr}$ classified by order of importance $\left(0.1\right.$ to $\left.26 \mathrm{mg} \cdot \mathrm{L}^{-1}\right) . \mathrm{Cu}, \mathrm{Zn}, \mathrm{Cr}$ and Ni were trace elements ( 0 to $30 \mu \mathrm{g} . \mathrm{L}^{-1}$ ). Nor Pb nor $\mathrm{Cd}$ was detected. The liquid phase was thus not a supply of high quantities of $\mathrm{Cu}, \mathrm{Zn}, \mathrm{Cr}$ and $\mathrm{Ni}$. The solid phase contained very high concentrations of $\mathrm{Ca}, \mathrm{Mg}, \mathrm{Sr}$, $\mathrm{Na}, \mathrm{K}, \mathrm{Fe}, \mathrm{Mn}$ and $\mathrm{Al}$ (up to $0.3 \mathrm{~g} . \mathrm{kg}^{-1}$ ) and $\mathrm{Zn}, \mathrm{Cu}, \mathrm{Cr}$ and $\mathrm{Ni}$ (up to $20 \mathrm{mg} \cdot \mathrm{kg}^{-1}$ ). The solid phase was thus a supply of high quantities of metals including $\mathrm{Zn}, \mathrm{Cu} \mathrm{Cr}$ and $\mathrm{Ni}$.

Compared to digested PS, the outdoor raw PS had 10 to 100 times higher $\mathrm{Cr}$ contents (Doelsch et al., 2010), 100 times higher Fe and $\mathrm{Al}$ contents (Sanchez et al., 2005, Legros et al., 2013), similar Ca, Mg and Ni concentrations (Doelsch et al., 2010; Legros et al., 2013; Sánchez and González, 2005), had 10 times smaller to similar Na and K concentrations and had 5 times lower to similar $\mathrm{Cu}$ and $\mathrm{Zn}$ contents (Doelsch et al., 2010; Legros et al., 2013; Li et al., 2010).

As a conclusion, the outdoor raw PS was here characterized by a low electrical conductivity with low inorganic nitrogen content. The liquid and solid phases were a high source of $\mathrm{Ca}, \mathrm{Mg}, \mathrm{Sr}, \mathrm{Na}, \mathrm{K}, \mathrm{Fe}, \mathrm{Mn}$ and $\mathrm{Al}$ while the solid phase was also an important source of $\mathrm{Cu}, \mathrm{Zn}, \mathrm{Cr}$ and Ni. PS was here particularly rich in $\mathrm{Fe}, \mathrm{Al}$ and $\mathrm{Cr}$.

\subsection{Description of soils controls (Table 2)}

TKN content in controls ranged from 0.3 to $7.5 \mathrm{~g} / \mathrm{kg}$ and decreased with depth that was consistent with the nitrogen supply by the important layer of dead leaves covering the soil. TKN (sum of ammonium and organic nitrogen) was here mainly organic nitrogen since TIN (nitrates, nitrites and ammonium) was lower than $2.1 \mathrm{mg}-\mathrm{N} / \mathrm{kg}$ that represented less than $3 \%$ of TKN.

Table 1

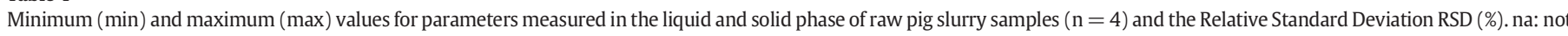
analyzed.

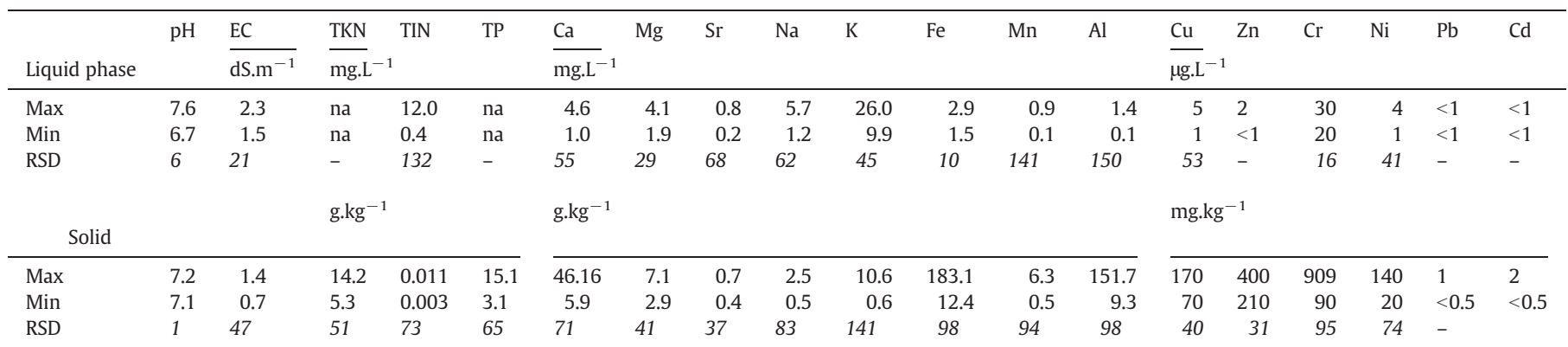


Table 2

Physicochemical properties of soils controls sampled at various depths: $0 \mathrm{~cm}, 25 \mathrm{~cm}$ and $65 \mathrm{~cm}$.

\begin{tabular}{|c|c|c|c|c|c|c|c|c|c|c|c|c|c|c|c|c|c|c|}
\hline \multicolumn{2}{|c|}{ Controls } & \multirow[t]{2}{*}{$\mathrm{pH}$} & \multirow{2}{*}{$\frac{\mathrm{EC}}{\mathrm{dS} . \mathrm{m}^{-1}}$} & \multirow{2}{*}{$\frac{\text { TKN }}{\mathrm{g} . \mathrm{kg}^{-1}}$} & \multirow[t]{2}{*}{$\mathrm{TP}$} & \multirow{2}{*}{$\frac{\mathrm{TIN}}{\mathrm{mg}-\mathrm{N} / \mathrm{kg}}$} & $\mathrm{Ca}$ & $\mathrm{Mg}$ & \multirow[t]{2}{*}{$\mathrm{Sr}$} & \multirow[t]{2}{*}{$\mathrm{Na}$} & \multirow[t]{2}{*}{ K } & \multirow[t]{2}{*}{$\mathrm{Fe}$} & \multirow[t]{2}{*}{$\mathrm{Mn}$} & \multirow[t]{2}{*}{$\mathrm{Al}$} & \multirow{2}{*}{\multicolumn{2}{|c|}{$\frac{\mathrm{Cu}}{\mathrm{mg} \cdot \mathrm{kg}^{-1}} \mathrm{Zn}$}} & \multirow[t]{2}{*}{$\mathrm{Cr}$} & \multirow[t]{2}{*}{$\mathrm{Ni}$} \\
\hline Sites & $\mathrm{cm}$ & & & & & & \multicolumn{2}{|c|}{$\overline{\text { g. } \mathrm{kg}^{-1} \text { g. } \mathrm{kg}^{-1}}$} & & & & & & & & & & \\
\hline \multirow[t]{3}{*}{$A_{1}$} & 0 & 7.7 & 0.2 & 5.2 & 2.4 & 1.9 & 295.2 & 1.5 & 5.3 & 2.0 & 0.3 & 20.2 & 0.7 & 15.8 & 29 & 75 & 133 & 23 \\
\hline & 25 & 8.1 & 0.1 & 0.7 & 0.5 & 2.1 & 381.2 & 0.5 & 7.5 & 2.1 & 0.05 & 5.2 & 0.1 & 3.4 & 4 & $<0.5$ & 36 & 1 \\
\hline & 65 & 8.4 & 0.6 & 1.0 & 0.6 & 0.4 & 390.1 & 1.2 & 7.1 & 2.1 & 0.06 & 5.8 & 0.2 & 3.8 & 10 & $<0.5$ & 48 & 3 \\
\hline \multirow[t]{3}{*}{$A_{2}$} & 0 & 7.6 & 0.4 & 7.5 & 2.2 & 0.003 & 284.3 & 0.9 & 5.3 & 1.5 & 0.3 & 15.7 & 0.5 & 11.9 & 15 & 20 & 88 & 15 \\
\hline & 25 & 7.3 & 0.2 & 4.9 & 1.7 & 0.002 & 304.1 & 0.8 & 5.7 & 1.7 & 0.2 & 17.3 & 0.5 & 12.7 & 13 & 13 & 125 & 20 \\
\hline & 65 & 8.6 & 0.3 & 0.6 & 0.4 & 0.0004 & 439.8 & 2.7 & 5.6 & 1.9 & 0.1 & 5.8 & 0.2 & 3.7 & 3 & 25 & 54 & 8 \\
\hline \multirow[t]{3}{*}{$B_{1} / B_{2}$} & 0 & 5.7 & 0.1 & 3.2 & 0.9 & 1.3 & 1.1 & 2.8 & 0.03 & 0.6 & 0.2 & 185.7 & 4.6 & 150.9 & 148 & 370 & 1020 & 167 \\
\hline & 25 & 5.6 & 0.1 & 1.0 & 0.7 & 1.3 & 0.1 & 2.4 & 0.01 & 0.1 & 0.01 & 218.4 & 3.5 & 171.3 & 164 & 148 & 1136 & 145 \\
\hline & 65 & 5.4 & 0.2 & 0.3 & 0.6 & 0.9 & 0.1 & 2.4 & $<0.01$ & 0.1 & 0.01 & 218.6 & 4.2 & 173.3 & 169 & 142 & 1091 & 143 \\
\hline \multirow[t]{3}{*}{$C_{1} / C_{2}$} & 0 & 6.0 & 0.9 & 3.7 & 1.6 & 1.4 & 6.3 & 7.6 & 0.08 & 1.6 & 1.0 & 194.1 & 4.2 & 105.0 & 115 & 274 & 1368 & 517 \\
\hline & 25 & 5.9 & 0.2 & 2.1 & 1.2 & 0.8 & 3.7 & 6.6 & 0.05 & 1.5 & 0.8 & 187.2 & 3.4 & 119.1 & 118 & 262 & 1206 & 556 \\
\hline & 65 & 5.8 & 0.5 & 0.7 & 1.1 & 0.6 & 2.2 & 5.0 & 0.08 & 1.1 & 0.3 & 166.4 & 2.0 & 132.1 & 104 & 176 & 867 & 565 \\
\hline
\end{tabular}

At Vaïlala, in the coastal area (Fig. 1), controls for $A_{1}$ and $A_{2}$, were characterized by alkaline $\mathrm{pH}$ values, very high Ca contents (295.2 to $439.8 \mathrm{~g} / \mathrm{kg}$ ) and high $\mathrm{Fe}, \mathrm{Al}, \mathrm{Sr}$ and $\mathrm{Mg}$ contents ( 0.5 to $20.2 \mathrm{~g} / \mathrm{kg}$ ). They were characteristic of mixed calcareous soils.

At Mont-Afala and at Lanutavake, inland (Fig. 1), controls for $B_{1}$ and $B_{2}$ and for $C_{1}$ and $C_{2}$ were slightly acidic and characterized by very high Fe and $\mathrm{Al}$ contents (105.9 to $218.6 \mathrm{~g} / \mathrm{kg}$ ) and high $\mathrm{Mn}$ and $\mathrm{Mg}$ contents (2.0 to $7.6 \mathrm{~g} / \mathrm{kg}$ ). Their $\mathrm{Cu}, \mathrm{Zn}, \mathrm{Ni}, \mathrm{Cr}, \mathrm{Pb}$ and $\mathrm{Cd}$ contents were much more important than for coastal soils. They were characteristic of pure ferralitic soils with quite similar composition, differing slightly by their $\mathrm{Ca}, \mathrm{Sr}, \mathrm{Na}, \mathrm{K}$ and Ni contents.

\subsection{Nitrogen and phosphorus contamination of soils}

Despite the large amount of TKN in PS (Table 1), only 3 samples exhibited a considerable or a very high CF for TKN (Table 3). The small TKN accumulation in most samples, after nitrogen supply by PS, could be attributed to a loss of $\mathrm{N}$-ammonia by volatilization, $\mathrm{N}$ uptake by crops and/ or nitrification (Jones et al., 2007; Morvan et al., 1997; Paul and Beauchamp, 1994).

For TIN, very high or considerable CF values were noticed in most samples (Table 3). TIN content in PS solid phase was low in comparison with the literature (3-11 mg-N/kg) (Table 1 ) but it was anyway ten times more concentrated than in soils controls (Table 2). Raw PS remained then an important source of TIN. Samples collected near concrete pens $\left(A_{1}, B_{1}\right.$ and $\left.C_{1}\right)$ had higher $C F$ values than those collected in land pens. PS accumulation near concrete pens was thus an important source of inorganic nitrogen. The high TIN contamination was also here due to in situ organic nitrogen mineralization of PS and by ammonium nitrification (Müller et al., 2003; Roth et al., 2014) in accordance with the low TKN CF.

For TP, very high or considerable CF values were noticed for four samples but in most cases $\mathrm{CF}$ was moderate or low (Table 3 ). Pig breeding on concrete pens $\left(A_{1}, B_{1}\right.$ and $\left.C_{1}\right)$ induced usually higher $C F$ for TKN, TIN and TP than breeding in land pens $\left(A_{2}, B_{2}\right.$ and $\left.C_{2}\right)$ (Table 3 ).

The exchangeable P content (Table 4 ) which was mainly phosphate ions was low in controls (below $1.4 \mathrm{mg} \cdot \mathrm{kg}^{-1}$ ) and it increased only for calcareous soils ( 190 and $42 \mathrm{mg} \cdot \mathrm{kg}^{-1} \mathrm{mg} / \mathrm{kg}$ for $\mathrm{A}_{1}$ and $\mathrm{A}_{2}$ respectively) in agreement with concentrations measured by Plaza et al. (2004). In impacted pure ferralitic soils, the exchangeable P content was not detected indicating that even though these soils were enriched with phosphorus, it was not exchangeable. This was due to phosphate adsorption on Fe and Al hydroxides and oxyhydroxides (Daroub et al., 2003; Fontes and Weed, 1996; Yerokun, 2008). Phosphate ions can't be drained to the groundwater in pure ferralitic soils but they can easily be in mixed calcareous soils.

Table 3

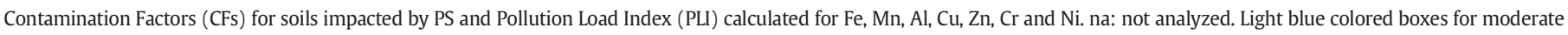
contamination, medium blue ones for considerable contamination and dark blue ones for very high contamination.

\begin{tabular}{|c|c|c|c|c|c|c|c|c|c|c|c|c|c|c|c|c|c|c|}
\hline Soils & Sites & depth & TKN & TIN & $\mathrm{TP}$ & $\mathrm{Ca}$ & $\mathrm{Mg}$ & $\mathrm{Sr}$ & $\mathrm{Na}$ & $\mathrm{K}$ & $\mathrm{Fe}$ & $\mathrm{Mn}$ & $\mathrm{Al}$ & $\mathrm{Cu}$ & $\mathrm{Zn}$ & $\mathrm{Cr}$ & $\mathrm{Ni}$ & PLI \\
\hline \multirow{6}{*}{ 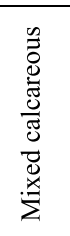 } & \multirow{3}{*}{$\mathrm{A}_{1}$} & 0 & 2.5 & 1.8 & 4.2 & & 3.0 & & & 6.4 & & & & 2.8 & 5.2 & & 1.8 & 1.3 \\
\hline & & 25 & 5.0 & 6.2 & 11.4 & & 4.0 & & & 12.2 & 2.6 & 2.7 & 3.1 & 8.9 & 9.2 & 3.3 & 27.1 & 5.5 \\
\hline & & 65 & & 23.8 & 1.6 & & 2.0 & & & 3.8 & & & & & & & & 0.5 \\
\hline & \multirow{3}{*}{$\mathrm{A}_{2}$} & 0 & & 2.2 & 2.1 & & 2.0 & & & 1.3 & 1.2 & & 1.2 & 1.8 & 25.2 & 1.5 & 6.1 & 2.5 \\
\hline & & 25 & & & 1.2 & & 1.1 & & & 1.3 & & & & 1.1 & 20.4 & & & 1.0 \\
\hline & & 65 & 7.5 & 14.3 & 4.2 & & & & & 3.2 & 2.1 & 1.1 & 2.9 & 4.9 & 3.5 & 1.6 & 1.7 & 2.3 \\
\hline \multirow{6}{*}{ 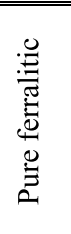 } & \multirow{3}{*}{$\mathrm{B}_{1}$} & 0 & 1.7 & 3.4 & 1.8 & 5.2 & & 2.8 & & 3.6 & & 1.2 & & 1.1 & & & & 0.9 \\
\hline & & 25 & & 5.7 & & 2.5 & & 6.7 & 1.4 & 11.7 & & 1.7 & & 1.1 & & & & 1.0 \\
\hline & & 65 & 1.5 & 9.0 & & 3.0 & & 12.2 & 1.4 & 11.6 & & 1.5 & & & & & & 1.0 \\
\hline & \multirow{3}{*}{$\mathrm{B}_{2}$} & 0 & $n a$ & 2.2 & $n a$ & $n a$ & $n a$ & $n a$ & $n a$ & na & $n a$ & $n a$ & $n a$ & $n a$ & $n a$ & $n a$ & $n a$ & $n a$ \\
\hline & & 25 & & & & 1.1 & & & 1.6 & 3.2 & & 1.6 & & 1.1 & & & 1.1 & 1.1 \\
\hline & & 65 & & 5.5 & 1.2 & & 1.1 & & 3.0 & 8.7 & & 1.9 & & 1.3 & 1.2 & 1.1 & 1.4 & 1.3 \\
\hline \multirow{6}{*}{ 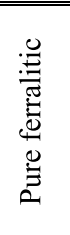 } & \multirow{3}{*}{$\mathrm{C}_{1}$} & 0 & 4.7 & 4.1 & 8.8 & 5.9 & 1.2 & 4.1 & & 4.5 & & & & & 2.1 & & & 0.7 \\
\hline & & 25 & & 11.7 & 1.3 & 1.2 & & 1.3 & & 1.6 & & & & & & & & 0.9 \\
\hline & & 65 & & 11.7 & 1.2 & 1.3 & 1.3 & & 1.1 & 3.4 & & 1.2 & & 1.1 & & & 1.2 & 1.0 \\
\hline & \multirow{3}{*}{$\mathrm{C}_{2}$} & 0 & & & 1.4 & & & & & 2.7 & & & & & & & & 0.9 \\
\hline & & 25 & 1.6 & & 1.6 & 1.5 & 1.2 & 1.3 & 1.2 & 3.2 & & & & & & & & 1.0 \\
\hline & & 65 & & & 1.4 & 1.1 & 2.0 & & & 2.6 & & 1.2 & & 1.2 & & & 1.1 & 1.1 \\
\hline
\end{tabular}


Table 4

Exchangeable contents in mg.kg-1 in soils sampled at the surface $(0 \mathrm{~cm}$ depth $)$.

\begin{tabular}{|c|c|c|c|c|c|c|c|c|c|c|c|c|c|c|}
\hline & Sites & $\mathrm{P}$ & $\mathrm{Ca}$ & $\mathrm{Mg}$ & $\mathrm{Sr}$ & $\mathrm{Na}$ & K & $\mathrm{Fe}$ & Mn & $\mathrm{Al}$ & $\mathrm{Cu}$ & $\mathrm{Zn}$ & $\mathrm{Cr}$ & $\mathrm{Ni}$ \\
\hline \multirow[t]{4}{*}{ Controls } & $\mathrm{A}_{1}$ & 1.4 & 2950 & 101 & 63 & 22 & 96 & 2.1 & 0.5 & 1.7 & 0.2 & 0.60 & $<0.01$ & $<0.01$ \\
\hline & $\mathrm{A}_{2}$ & 1.2 & 3400 & 73 & 97 & 15 & 99 & 4.4 & 1.0 & 4.1 & 0.2 & 0.02 & $<0.01$ & $<0.01$ \\
\hline & $\mathrm{B}_{1} / \mathrm{B}_{2}$ & $<0.1$ & 580 & 150 & 11 & 41 & 76 & 14.5 & 141.1 & 13.7 & 0.1 & 1.02 & 0.01 & 0.43 \\
\hline & $\mathrm{C}_{1} / \mathrm{C}_{2}$ & $<0.1$ & 3055 & 1047 & 38 & 187 & 199 & 20.7 & 47.2 & 16.8 & 0.2 & 0.40 & 0.02 & 0.20 \\
\hline \multirow[t]{6}{*}{ Impacted soils } & $\mathrm{A}_{1}$ & 190 & 4095 & 710 & 81 & 85 & 795 & 13 & 3.1 & 8.8 & 0.8 & 1.10 & 0.07 & 0.04 \\
\hline & $\mathrm{A}_{2}$ & 42 & 3720 & 360 & 90 & 57 & 645 & 16 & 1.3 & 14.0 & 0.5 & 1.20 & 0.06 & 0.04 \\
\hline & $\mathrm{B}_{1}$ & $<0.1$ & 3795 & 243 & 70 & 55 & 260 & 13 & 2.1 & 10.1 & 0.5 & 0.06 & $<0.01$ & $<0.01$ \\
\hline & $\mathrm{B}_{2}$ & $<0.1$ & 1565 & 545 & 25 & 140 & 750 & 10 & 89.5 & 8.2 & 0.2 & 0.84 & $<0.01$ & 0.04 \\
\hline & $C_{1}$ & $<0.1$ & 4560 & 930 & 45 & 53 & 844 & 8 & 9.4 & 6.3 & 0.2 & 2.10 & $<0.01$ & 0.05 \\
\hline & $\mathrm{C}_{2}$ & $<0.1$ & 3055 & 1050 & 32 & 45 & 790 & 8 & 20.8 & 6.3 & 0.2 & 0.50 & $<0.01$ & 0.08 \\
\hline
\end{tabular}

\subsection{Increase of soils salinity}

Soils impacted by PS exhibited higher EC than their control (the ratio at the surface $\mathrm{EC}_{\text {impacted }} / \mathrm{EC}_{\text {control }}$ was 6.5 and 8.6 for $\mathrm{A}_{1}$ and $\mathrm{A}_{2}$ respectively, 5.5 for $B_{1}, 3.3$ and 2.7 for $C_{1}$ and $C_{2}$ respectively).

$\mathrm{Ca}, \mathrm{Mg}, \mathrm{Sr}$, Na and $\mathrm{K}$ were highly concentrated in PS liquid and solid phases ( 0.2 to $26.0 \mathrm{mg} . \mathrm{L}^{-1}$ and 0.4 to $41.6 \mathrm{~g} . \mathrm{kg}^{-1}$ respectively) (Table 1). Even though, CF values for total $\mathrm{Ca}, \mathrm{Mg}$, $\mathrm{Sr}$ and Na were not systematically high because their concentrations in PS was, depending on the soils considered, irrelevant in front of natural total contents. CF values for total $\mathrm{K}$ indicated that at least a moderate contamination existed (Table 3 ). $\mathrm{K}$ was accumulated in all cases and a significant positive correlation $\left(R^{2}=0.762\right)$ was obtained between EC and total K content in all soils samples (controls and impacted ones) indicating that EC increase was mainly related to $\mathrm{K}$ enrichment. $\mathrm{CF}$ values for the exchangeable fraction of $\mathrm{K}$ were always considerable or very high (Table 5). CF for the exchangeable fraction of $\mathrm{Ca}, \mathrm{Mg}, \mathrm{Sr}$ and Na were above one (except $\mathrm{Sr}$ at $\mathrm{A}_{2}$, Mg and $\mathrm{Na}$ for $\mathrm{C}_{1}$ and except for $\mathrm{C}_{2}$ ) indicating that these elements contributed to increase soils EC. Beside inorganic nitrogen enrichment in impacted soils, the soil salinity increase was related to $\mathrm{Ca}, \mathrm{Sr}, \mathrm{Mg}$, $\mathrm{Na}$ and $\mathrm{K}$ supply.

These metals have no detrimental effects but it is known that salinity increases the mobility of heavy metals in soils or sediments by competition for sorption sites (Acosta et al., 2011; Zhao et al., 2013). Salinization due to PS inputs has thus to be taken into account when assessing the risk on heavy metals release.

\subsection{Heavy metals contamination in calcareous soils}

Fe, Mn and Al were highly concentrated in PS liquid and solid phases ( 0.1 to $2.9 \mathrm{mg} . \mathrm{L}^{-1}$ and 0.5 to $183.1 \mathrm{~g} . \mathrm{kg}^{-1}$ respectively) (Table 1 ). Consequently for calcareous soils $\left(\mathrm{A}_{1}\right.$ and $\left.\mathrm{A}_{2}\right)$ naturally poor in $\mathrm{Fe}, \mathrm{Al}$ and Mn (Table 2), CF values indicated moderate to high contaminations, at least at one layer (Table 3). Calcareous soils were naturally poor in $\mathrm{Cu}$, $\mathrm{Zn}, \mathrm{Cr}$ and Ni (Table 2) thus PS inputs (20 to $909 \mathrm{mg} \cdot \mathrm{kg}^{-1}$ in PS solid phase) (Table 1 ) induced also moderate to high CF for total contents at least at one depth (Table 3). The PLI index (Table 3) demonstrated

\section{Table 5}

Contamination Factors in the exchangeable fraction for soils impacted by PS. Light blue colored boxes for moderate contamination, medium blue ones for considerable contamination and dark blue ones for very high contamination.

\begin{tabular}{|c|c|c|c|c|c|c||c|c|c|c|c|}
\hline \multicolumn{1}{|c|}{$\begin{array}{c}\text { Depth: 0 cm } \\
\text { Mixed }\end{array}$} & $\mathrm{Ca}$ & $\mathrm{Mg}$ & $\mathrm{Sr}$ & $\mathrm{Na}$ & $\mathrm{K}$ & $\mathrm{Fe}$ & $\mathrm{Mn}$ & $\mathrm{Al}$ & $\mathrm{Cu}$ & $\mathrm{Zn}$ \\
\hline \begin{tabular}{c} 
calcareous \\
\cline { 4 - 12 }
\end{tabular} & $\mathrm{A}_{2}$ & 1.4 & 7.0 & 1.3 & 3.9 & 8.3 & 5.8 & 6.7 & 5.3 & 4.0 & 1.8 \\
\hline \hline $\begin{array}{c}\text { Pure } \\
\text { ferralitic }\end{array}$ & $\mathrm{B}_{1}$ & 6.6 & 1.7 & 6.1 & 1.4 & 3.4 & 0.9 & 0.02 & 0.8 & 5.0 & 0.1 \\
\cline { 2 - 13 } & $\mathrm{B}_{2}$ & 2.7 & 3.6 & 2.2 & 3.4 & 9.9 & 0.7 & 0.7 & 0.6 & 2.0 & 0.8 \\
\hline \hline \multirow{2}{*}{$\begin{array}{c}\text { Pure } \\
\text { ferralitic }\end{array}$} & $\mathrm{C}_{1}$ & 1.5 & 0.9 & 1.2 & 1.0 & 4.2 & 0.4 & 0.2 & 0.4 & 1.5 & 5.3 \\
\cline { 2 - 12 } & $\mathrm{C}_{2}$ & 1.0 & 1.0 & 0.9 & 0.9 & 4.0 & 0.4 & 0.4 & 0.4 & 1.0 & 1.0 \\
\hline
\end{tabular}

that heavy metals pollution existed ( $1.3,5.5$ for $A_{1}$ at 0 and $25 \mathrm{~cm}$ depths and 2.5 and 2.3 for $A_{2}$ at 0 and $65 \mathrm{~cm}$ depths).

Additionally, $\mathrm{CF}$ values for the exchangeable fraction of $\mathrm{Fe}, \mathrm{Mn}, \mathrm{Al}, \mathrm{Cu}$ and $\mathrm{Zn}$ indicated that PS inputs induced moderate to very high contamination in this soil fraction (Table 5). It demonstrates that either PS provided exogenous soluble $\mathrm{Fe}, \mathrm{Mn}, \mathrm{Al}, \mathrm{Cu}$ and $\mathrm{Zn}$ or endogenous $\mathrm{Fe}, \mathrm{Mn}, \mathrm{Al}$, $\mathrm{Cu}$ and $\mathrm{Zn}$ became exchangeable. $\mathrm{CF}$ for the exchangeable fraction of $\mathrm{Cr}$ and $\mathrm{Ni}$ could not be calculated; they were detected in impacted soils (Table 4) but not in controls indicating that they were mobile in impacted soils. With PS inputs, soil pH decreased ( 0.5 and 0.1 unit for $A_{1}$ and $A_{2}$ respectively at the surface) and soil salinity increased. Both parameters are known to have a positive influence on metals's solubility and thus metals' mobility (Gunkel et al., 2002; Zeng et al., 2011). In impacted mixed calcareous soils $\mathrm{Fe}, \mathrm{Mn}, \mathrm{Al}, \mathrm{Cu}, \mathrm{Zn}, \mathrm{Cr}$ and Ni mobility enhancement was related to $\mathrm{pH}$ decrease and salinity increase.

\subsection{Heavy metals contamination in ferralitic soils}

Fe and Al contents were naturally high in ferralitic soils $\left(B_{1}, B_{2}, C_{1}\right.$ and $C_{2}$ ) (Table 2). $\mathrm{CF}$ for total $\mathrm{Fe}$ and $\mathrm{Al}$ always indicated a nil contamination (Table 3 ) because Fe and Al supply by PS was insignificant in front of natural high contents. Mn supply could be detected in front of natural contents (Table 2) inducing a moderate contamination at least at one depth (Table 3). Few CF values indicated moderate $\mathrm{Zn}, \mathrm{Cr}$ and Ni contaminations (Table 3 ) because they were minor elements in PS. Among minor elements in PS, Cu was the one with lowest concentrations in ferralitic soils (Table 2) thus Cu supply was relevant and its CF indicated moderate contamination at least at one depth (Table 3). Some PLIs for breeding in land pens were slightly up to one (Table 3) demonstrating a small heavy metals pollution (1.1, 1.3 for $\mathrm{B}_{2}$ at 25 and $65 \mathrm{~cm}$ depth and 1.1 for $C_{2}$ at $65 \mathrm{~cm}$ depth).

$\mathrm{CF}$ for the exchangeable fraction of $\mathrm{Fe}, \mathrm{Mn}$ and $\mathrm{Al}$ were below 1 (Table 5) underlying that the exchangeable content of Fe, Mn and Al decreased with PS inputs. For $\mathrm{Cr}$ and $\mathrm{Ni}, \mathrm{CF}$ could not be calculated because they were not detected in most impacted soils (Table 4) while they were in controls (Table 4) indicating that their concentrations decreased in the exchangeable fraction. With PS, the soil pH has increased of $1.4,0.7,1.4$ and $1.4 \mathrm{pH}$ units for $\mathrm{B}_{1}, \mathrm{~B}_{2}, \mathrm{C}_{1}$ and $\mathrm{C}_{2}$ respectively. Yuan et al. (2007) demonstrated that $\mathrm{Cu}$ and $\mathrm{Cd}$ desorption in soils increases with the increase of ionic strength while the desorption decreases with the rise of $\mathrm{pH}$. They explained that desorption mechanism is a competition of complexation, adsorption and precipitation. For $\mathrm{Fe}, \mathrm{Mn}, \mathrm{Al}, \mathrm{Cr}$ and $\mathrm{Ni}$, the net effect of all these competitive reactions was here a decrease of their mobility. Results for $\mathrm{Zn}$ were variable. For $\mathrm{B}_{1}$ and $\mathrm{B}_{2}$, $\mathrm{CF}$ values were below one indicating here its immobilization like $\mathrm{Fe}, \mathrm{Mn}, \mathrm{Al}, \mathrm{Cr}$ and $\mathrm{Ni}$. $\mathrm{Zn}$ and $\mathrm{Mn}$ immobilization in contaminated soils had also been observed after "alperujo" compost application (Alburquerque et al., 2011). But a considerable contamination is noticed for $\mathrm{Zn}$ in $\mathrm{C}_{1}$ (Table 5) and for $\mathrm{Cu}$ in $\mathrm{B}_{1}, \mathrm{~B}_{2}$ and $\mathrm{C}_{1}$. Humic and fulvic acids in PS are characterized by a very small $\mathrm{Cu}$ (II) and $\mathrm{Zn}$ (II) binding capacity and stability constant with respect to natural soil humic and fulvic acids 
(Hernández et al., 2006; Plaza et al., 2005). Cu and Zn could anyway move in the exchangeable fraction by binding with soluble organic matter provided by PS. Dissolved organic matter chelating properties are known to be improved by an increase of $\mathrm{pH}$ due to deprotonation of binding functions. High $\mathrm{CF}$ in the exchangeable fraction for $\mathrm{Cu}$ was then probably due to its chelation with dissolved organic matter. $\mathrm{Zn}$ is known to be less mobilized than $\mathrm{Cu}$ with organic acids (Pérez-Esteban et al., 2013). $B_{1}$ and $B_{2}$ had lower $p H$ than $C_{1}$ at the surface (7.1, 6.4 and 7.4 respectively) and dissolved organic matter binding capacity enhancement and the EC enhancement could probably not counterbalance $\mathrm{Zn}$ immobilization by soil alkalinisation. The exchangeable $\mathrm{Cu}$, $\mathrm{Zn}, \mathrm{Cr}$ and Ni content remained anyway low in comparison with previous metals (below $2.1 \mathrm{mg} \cdot \mathrm{kg}^{-1}$ ) (Table 4) in agreement with values measured in tropical ferralitic soils in Reunion Island amended by PS (Doelsch et al., 2010).

\section{Conclusion}

To the best of our knowledge, this study is the first of its kind on family pig farming in tropical islands. A long term application of raw pig slurry on soils can lead to an increase of nitrogen, phosphorus and metals contents. The soil layer that concentrates inputs is not necessary the top layer, it is thus important to collect soils samples at various depths.

This study underlines that the behavior of contaminants is related to the nature of the tropical soil. For mixed calcareous soils at the coastal area, a fraction of phosphorus is mobile and soils are enriched with $\mathrm{Fe}$, $\mathrm{Mn}, \mathrm{Al}, \mathrm{Cu}, \mathrm{Zn}, \mathrm{Cr}$ and $\mathrm{Ni}$ which are exchangeable. Pig breeding may then induce fluxes of these elements to the ground water. For inland pure ferralitic soils, $\mathrm{P}, \mathrm{Fe}, \mathrm{Mn}, \mathrm{Al}, \mathrm{Cr}$ and $\mathrm{Ni}$ are immobilized. $\mathrm{Cu}$ remain mobile and sometimes $\mathrm{Zn}$ as well. Inland, several meters of soils separate the soil surface from the groundwater limiting the drainage risk of contaminants. Detrimental effects of pig slurry can be important for mixed calcareous soils at the coastal area concentrating moreover most inhabitants.

Globally, pig breeding on concrete pens induces higher Contamination Factors for organic nitrogen, inorganic nitrogen en total phosphorus than breeding in land pens.

Based upon these results and for groundwater preservation, it is then recommended to limit family pig breeding on concrete pens without pig slurry management on coastal calcareous soils and rather encourage the use of large land pens on ferralitic soils in Uvéa and by spread in volcanic islands in the south Pacific.

\section{Acknowledgments}

The authors are grateful to the French "Ministère de l'Outre Mer" (scheduling 2010), the Universities of Reims Champagne Ardenne and of New-Caledonia for the financial support of ELEP (Etude des Lisiers des Elevages Porcins) program and the people of Uvea for their kind welcome. We are also grateful to the reviewers whose judicious comments have greatly improved the manuscript.

\section{References}

Acosta, J.A., Jansen, B., Kalbitz, K., Faz, A., Martínez-Martínez, S., 2011. Salinity increases mobility of heavy metals in soils. Chemosphere 85 (8), 1318-1324.

Alburquerque, J.A., de la Fuente, C., Bernal, M.P., 2011. Improvement of soil quality after "alperujo" compost application to two contaminated soils characterised by differing heavy metal solubility. J. Environ. Manag. 92, 733-741.

Alory, G., Delcroix, T., 1999. Climatic variability in the vicinity of Wallis, Futuna, and Samoa islands (13"-15" S, $180^{\circ}-1700$ W). Oceanol. Acta 22 (3), 249-263.

Daroub, S.H., Gerakis, A., Ritchie, J.T., Friesen, D.K., Ryan, J., 2003. Development of a soilplant phosphorus simulation model for calcareous and weathered tropical soils. Agric. Syst. 76, 1157-1181.

De la Torre, A.I., Jimenez, J.A., Carballo, M., Fernandez, C., Roset, J., Muñoz, M.J., 2000. Ecotoxicological evaluation of pig slurry. Chemosphere 41, 1629-1635.
Doelsch, E., Masion, A., Moussard, G., Chevassus-Rosset, C., Wojciechowicz, O., 2010. Impact of pig slurry and green waste compost application on heavy metal exchangeable fractions in tropical soils. Geoderma 155, 390-400.

Fangueiro, D., Gusmao, M., Grilo, J., Porfirio, J., Vasconcelos, E., Cabral, F., 2010. Proportion composition and potential $\mathrm{N}$ mineralisation of particle size fractions obtained by mechanical separation of animal slurry. Biosyst. Eng. 106, 333-337.

Fediavesky, A., Angus, S., 2002. "Pig Farming in Wallis Island: Pollution Risks and Development Proposals". S.r.d.s animale vol. 2010. Commission Pacifique Sud, Suva (edn).

Fontes, M.P.F., Weed, S.B., 1996. Phosphate adsorption by clays from Brazilian Oxisols: relationships with specific surface area and mineralogy. Geoderma 72, 37-51.

Fujita, M., Ide, Y., Sato, D., Kench, P.S., Kuwahara, Y., Yokoki, H., Kayanne, H., 2014. Heavy metal contamination of coastal lagoon sediments: Fongafale Islet, Funafuti Atoll, Tuvalu. Chemosphere 95, 628-634.

Gunkel, P., Jézéquel, K., Fabre, B., 2002. Temporal evolution of copper distribution in soil fractions, influence of soil pH and organic carbon level on copper distribution. Environ. Technol. 23 (9), 1001-1008.

Gwod, S.S., Reddy, M.R., Govil, P.K., 2010. Assessment of heavy metal contamination in soils at Jajmau (Kanpur) and Unnao industrial areas of the Ganga Plain, Uttar Pradesh, India. J. Hazard. Mater. 174, 113-121.

Håkanson, L., 1980. An ecological risk index for aquatic pollution control. A sedimentological approach. Water Res. 14, 975-1001.

Hansen, M.J., Chwalibog A., Tauson, A.-H., 2007. Influence of different fibre sources in diets for growing pigs on chemical composition of faces and slurry and ammonia emission from slurry. Anim. Feed Sci. Technol. 134, 326-336.

Hernández, D., Plaza, C., Senesi, N., Polo, A., 2006. Detection of Copper(II) and zinc(II) binding to humic acids from pig slurry and amended soils by fluorescence spectroscopy. Environ. Pollut. 143, 212-220.

Iqbal, J., Shah, M.H., 2011. Distribution, correlation and risk assessment of selected metals in urban soils from Islamabad, Pakistan. J. Hazard. Mater. 192, 887-898.

ISO/DIS19730, 2006. Soil Quality - Extraction of Trace Elements Using Ammonium Nitrate Solution. Organization for Standartization.

Jones, S.K., Rees, R.M., Skiba, U.M., Ball, B.C., 2007. Influence of organic and mineral N fertiliser on N2O fluxes from a temperate grassland. Agric. Ecosyst. Environ. 121, 74-83.

L'Herroux, L., Le Roux, S., Appriou, P., Martinez, J., 1997. Behaviour of metals following intensive pig slurry applications to a natural field treatment process in Brittany (France). Environ. Pollut. 97 (1-2), 119-130.

Legros, S., Doelsch, E., Feder, F., Moussard, G., Sansoulet, J., Gaudet, J.-P., Rigaud, S., Basile Doelsch, I., Saint Macary, H., Bottero, J.Y., 2013. Fate and behaviour of $\mathrm{Cu}$ and $\mathrm{Zn}$ from pig slurry spreading in a tropical water-soil-plant-system. Agric. Ecosyst. Environ. $164,70-79$.

Li, L., Xu, Z., Wu, J., Tian, G., 2010. Bioaccumulation of heavy metals in the earthworm Eisenia fetida in relation to bioavailable metal concentrations in pig manure. Bioresour. Technol. 101, 3430-3436.

Li, Z., Ma, Z., Jan van der Kuijp, T., Yuan, Z., Huang, L., 2014. A review of soil heavy metal pollution from mines in China: pollution and health risk assessment. Sci. Total Environ. 468-469, 843-853.

Moral, R., Perez-Murcia, M.D., Perez-Espinosa, A., Moreno-Caselles, J., Paredes, C., 2005. Estimation of nutrient values of pig slurries in Southeast Spain using easily determined properties. Waste Manag. 25, 719-725.

Morvan, T., Leterme, Ph., Arsene, G.G., Mary, B., 1997. Nitrogen transformations after the spreading of pig slurry on bare soil and ryegrass using $15 \mathrm{~N}$-labelled ammonium. Eur. J. Agron. 7, 181-188.

Müller, C., Stevens, R.J., Laughin, R.J., 2003. Evidence of carbon stimulated N transformations in grassland soil after slurry application. Soil Biol. Biochem. 35, 285-293.

Paul, J.W., Beauchamp, E.G., 1994. Availability of manure slurry ammonium for corn using tsN-labelled (NH4)2SO4. Can. J. Soil Sci. 35-42.

Payet, N., Findeling, A., Chopart, J.L., Feder, F., Nicolini, E., Saint, Macary H., Vauclin, M., 2009. Modelling the fate of nitrogen following pig slurry application on a tropical cropped acid soil on the island of Réunion (France). Agric. Ecosyst. Environ. 134, 218-233.

Pérez-Esteban, J., Escolástico, C., Moliner, A., Masaguer, A., 2013. Chemical speciation and mobilization of copper and zinc in naturally contaminated mine soils with citric and tartaric acids. Chemosphere 90, 276-283.

Plaza, C., Hernández, D., García-Gil, J.C., Polo, A., 2004. Microbial activity in pig-slurry amended soils under semiarid conditions. Soil Biol. Biochem. 36 (2004), 1577-1585.

Plaza, C., Senesi, N., García-Gil, J.C., Polo, A., 2005. Copper (II) complexation by humic and fulvic acids from pig slurry and amended and non-amended soils. Chemosphere 61, 711-716.

Price, R.C., Maillet, P., McDougall, I., Dupont, J., 1991. The geochemistry of basalts from the Wallis Islands, northern Melanesian borderland: evidence for a lithospheric origin for Samoan-type basaltic magmas? J. Volcanol. Geotherm. Res. 45, 267-288.

Provolo, G., Martinez-Suller, L., 2007. In situ determination of slurry nutrient content by electrical conductivity. Bioresour. Technol. 98, 3235-3242.

Roth, E., Gunkel-Grillon, P., Joly, L., Thomas, X., Decarpenterie, T., Mappe-Fogaing, I., LaporteMagoni, C., Dumelié, N., Durry, G., 2014. Impact of raw pig slurry and pig farming practices on physicochemical parameters and on atmospheric $\mathrm{N}_{2} \mathrm{O}$ and $\mathrm{CH}_{4}$ emissions of tropical soils, Uvéa Island (South Pacific). Environ. Sci. Pollut. Res. 21, 10022-10035.

Sánchez, M., González, J.L., 2005. The fertilizer value of pig slurry. I. Values depending on the type of operation. Bioresour. Technol. 96, 1117-1123.

Stearns, H.T., 1945. Geology of the Wallis Islands. Geol. Soc. Am. Bull. 56, 849-860.

Tercinier, G., 1971. Les sols bauxitiques de karst des atolls surélevés du Pacifique : contribution à l'étude des phénomènes de bauxitisation et d'allitisation. In: Douzième congrès du Pacifique (Ed.), Science du Sol, 1972. Congrès du Pacifique, 12, Canberra, pp. 103-122. 
Tomlinson, D.L., Wilson, J.G., Harris, C.R., Jeffrey, D.W., 1980. Problems in the assessment of heavy-metal levels in estuaries and the formation of a pollution index. Helgolander Meeresunters. 33, 566-575.

van der Stelt, B., Temminghoff, E.J.M., van Riemsdijk, W.H., 2005. Measurement of ion speciation in animal slurries using the Donnan Membrane Technique. Analytica. Chimica. Acta. 552 (1-2), 135-140.

Yerokun, O.A., 2008. Chemical characteristics of phosphorus in some representative benchmark soils of Zambia. Geoderma 147, 63-68.
Yuan, S., Xi, Z., Jiang, Y., Wan, J., Wu, C., Zheng, Z., Lu, X., 2007. Desorption of copper and cadmium from soils enhanced by organic acids. Chemosphere 68, 1289-1297.

Zeng, F., Ali, F., Zhang, H., Ouyang, Y., Qiu, B., Wu, F., 2011. The influence of pH and organic matter content in paddy soil on heavy metal availability and their uptake by rice plants. Environ. Pollut. 159, 84-91.

Zhao, S., Chenghong, Feng C., Wang, D., Liu, Y., Shen, Z., 2013. Salinity increases the mobility of $\mathrm{Cd}, \mathrm{Cu}, \mathrm{Mn}$, and $\mathrm{Pb}$ in the sediments of Yangtze Estuary: relative role of sediments' properties and metal speciation. Chemosphere 91, 977-984. 